\title{
The Current and Future Uses of Biotechnology in Animal Agriculture
}

\author{
Alison L. Van Eenennaam ${ }^{1}$
}

\begin{abstract}
Biotechnologies have been an integral part of improvements in animal genetics, nutrition and health over the past century. Many biotechnologies have become fundamental components of efficient livestock production systems. The genetic improvements that have been enabled by biotechnologies have dramatically decreased the environmental footprint of animal protein production in many parts of the world, and continued innovation is required to address the projected increase in demand for animal products in the future. Breeding programs increasingly utilize a combination of advanced reproductive technologies and genomic tools to accelerate the rate of genetic gain by manipulating components of the breeder's equation. The use of these biotechnologies and breeding methods has met with little public opposition. In contrast, the use of modern biotechnologies, defined as those that employ the use of in vitro nucleic acid techniques, have been highly controversial, especially those involving the use of genetic engineering. This modern biotechnology distinction is somewhat arbitrary as there are a number of biotechnologies that involve the use of in vitro processes, and many result in genetic modifications that are indistinguishable from the naturally-occurring variation that is the driver of both traditional breeding programs and evolution. A number of useful traits including disease resistance and animal welfare traits have been successfully introduced into various livestock species using both genetic engineering and gene editing techniques. Ultimately these techniques complement the genetic improvement that can be accomplished using traditional selection techniques and, if judged acceptable, offer an opportunity to synergistically accelerate genetic improvement in food animal species.
\end{abstract}

Key words: Biotechnology, gene editing, genetic engineering

\section{Los Usos Actuales y Futuros de la Biotecnología en la Agricultura Pecuaria}

Resumen. Las biotecnologías han sido una parte integral de las mejoras en la genética animal, nutrición y sanidad a lo largo del siglo pasado. Muchas biotecnologías se han vuelto componentes fundamentales de los sistemas de producción pecuaria eficientes. Las mejoras genéticas que han sido habilitadas por las biotecnologías han disminuido dramáticamente la huella ambiental de la producción de proteína animal en muchas partes del mundo, e innovaciones continuas son necesarias para cumplir con el aumento proyectado en la demanda para los productos animales en el futuro. Los programas de reproducción cada vez más usan una combinación de tecnologías reproductivas avanzadas y las herramientas genómicas para acelerar la tasa de ganancia genética al manipular los componentes de la ecuación del reproductor. El uso de estas biotecnologías y métodos de crianza se ha encontrado con poca oposición pública. En contraste, el uso de tecnologías modernas, definidas como aquellas que usan técnicas de ácidos nucleicos in vitro ha sido altamente controversial, especialmente aquellas que involucran el uso de ingeniería genética. Esta distinción de biotecnología moderna es algo arbitraria ya que hay un número de biotecnologías que involucran el uso de procesos in vitro, y muchos resultan en modificaciones genéticas que no se pueden distinguir de la variación que ocurre naturalmente y que es el impulsor de programas de crianza y la evolución. Un número de características útiles incluyendo la resistencia a enfermedades y las características de bienestar animal han sido introducidas con éxito en varias especies de animales pecuarios usando la ingeniería genética y técnicas de edición genética. Por último, estas técnicas complementan las mejoras genéticas que pueden lograrse usando técnicas de selección tradicional y si es aceptable, ofrecen una oportunidad para acelerar el mejoramiento genético con sinergia en especies animales.

Palabras clave: Biotecnología, edición de genes, ingeniería genética.

${ }^{1}$ Department of Animal Science, University of California, Davis, CA 95616. Email: alvaneenennaam@ucdavis.edu

DOI: $10.5377 /$ ceiba.v54i1.2782 


\section{Introducción}

Biotechnology is defined in the Cartagena protocol as "any technological application that uses biological systems, living organisms, or derivatives thereof, to make or modify products or processes for specific use." From this definition it is clear that some applications of biotechnology have been used in animal agriculture for many years. Biotechnologies have directly benefitted the three core scientific disciplines of animal science - genetics, nutrition, and health, as summarized in Table 1 (FAO 2010).

Table 1. Biotechnologies used in animal production (adapted from FAO 2010).

\begin{tabular}{l|l|l}
\hline Genetics/breeding & Nutrition & Health \\
\hline Artificial insemination & Single cell proteins & Molecular diagnostics \\
\hline Progesterone monitoring & Probiotics and Prebiotics & DNA vaccines \\
\hline Estrus synchronization & Recombinant somatotropins & Marker vaccines \\
\hline $\begin{array}{l}\text { In vitro fertilization and embryo } \\
\text { transfer }\end{array}$ & $\begin{array}{l}\text { Solid state fermentation of } \\
\text { lignocellulosics }\end{array}$ & Virus-vectored vaccines \\
\hline $\begin{array}{l}\text { Molecular markers; Marker- } \\
\text { assisted and genomic selection }\end{array}$ & $\begin{array}{l}\text { Feed additives: Amino acids, enzymes \& } \\
\text { probiotics }\end{array}$ & Sterile insect technique (SIT) \\
\hline Cryopreservation & lonophores & Bioinformatics \\
\hline Semen and embryo sexing & Molecular gut microbiology & \\
\hline Cloning & $\begin{array}{l}\text { Silage additives (enzymes and microbial } \\
\text { inoculants) }\end{array}$ & \\
\cline { 1 - 2 } Genetic & Recombinant metabolic modifiers & \\
Engineering/Transgenesis & & \\
\hline Genome Editing & &
\end{tabular}

To impact the rate of genetic change $(\Delta \mathrm{G})$ in a breeding program, biotechnologies must impact some component of the breeder's equation:

$$
\Delta G=\frac{[(\text { Accuracy of Selection }) \times(\text { Selection Intensity }) \times(\text { Genetic Standard Deviation })]}{\text { Generation Interval }}
$$

Artificial insemination (Al) is a biotechnology that greatly increases the selection intensity by enabling the high use of genetically superior sires. Al plays a major role in design of breeding programs and dissemination of advanced genetics. Al technology was introduced into the dairy industry and commercialized in the United States during the late 1930s to early 1940s (Foote 1999). Today, approximately $80 \%$ of all dairy cows in the US are bred using Al.

To put the extensive use of Al in the US dairy industry in perspective, a single US bull named Elevation, born in 1965, had over 80,000 daughters, 2.3 million granddaughters, and 6.5 million greatgranddaughters (VanRaden 2007). Such extensive use of this single exceptional bull clearly accelerated the rate of genetic gain, but also has the potential to reduce the genetic diversity of the dairy cattle population. About half of the $369 \%$ increase in milk production efficiency (Figure 1) is attributable to genetic improvement enabled by $\mathrm{Al}$; the remainder is due to improved management and nutrition.

Although $\mathrm{Al}$ is used routinely in animal breeding, it was initially viewed with skepticism. There was a fear that $\mathrm{Al}$ would lead to abnormalities, and influential cattle breeders were originally opposed to the concept as they believed it would destroy their bull market (Foote 2002). When independent, university research demonstrated that the $\mathrm{Al}$ could be used to provide superior bulls, control venereal disease, and produce healthy calves, subsequent industry adoption was swift. 


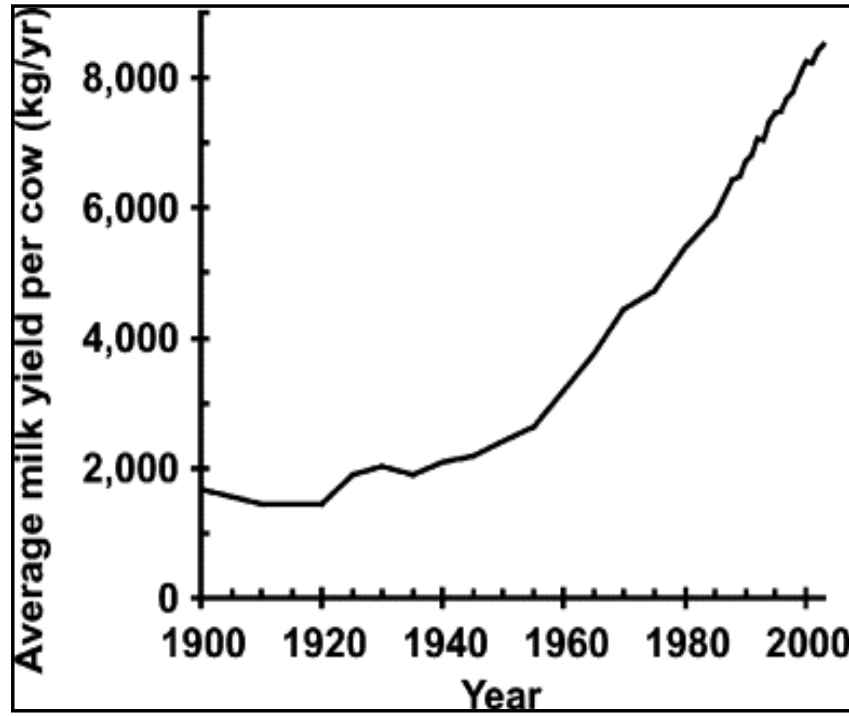

Figure 1. Milk production per cow in the United States over the past 100 years (VandeHaar and St-Pierre 2006).

It has been observed that despite intense selection on specific traits (e.g. 8-week body weight in broilers or milk yield in dairy cattle), the selection response per generation for these traits shows no sign of decreasing. Mean milk yield in the U.S. has increased at a rate of $1 \%$ per generation for decades. It is likely that this sustained response is fueled by new mutations that arise each generation (Hill and Kirkpatrick 2010).

From an environmental perspective, genetic improvement over the past 50 years has also resulted in reductions in greenhouse gas (GHG) emissions and global warming potential per ton of animal product (Table 2; Jones et al. 2008). Capper et al. (2009) reported that although the carbon footprint per individual cow increased when comparing 1944 to 2007 due to increases in the milk production per cow, the carbon footprint per unit of milk in 2007 was $63 \%$ lower than in 1944. Progress in decreasing the environmental footprint per unit of ruminant meat production has been noticeably less than in other animal-source proteins.

Industries that have less vertical integration (e.g. beef and sheep) have generally made slower genetic progress. Animal breeding in these industries tends to be driven by breed associations, and because the traits differ among industry sectors (e.g. breeder, farmer, feeder, processor); it is difficult to develop a single, industry-wide breeding objective that is economically rational for all sectors. This leads to an important concept in animal breeding, the role of the decision maker (Olesen et al. 2000). In the absence of vertical integration, breeding goals will be developed based on the producers' financial interests. The producer is the one investing in breeding stock and in a competitive market their decision will be based on the ways they perceive that animals contribute to farm profit.

Table 2. Proportional changes (\%) in greenhouse gas (GHG) emissions and global warming potential $\left(G P_{100}\right)$ per unit of animal product achieved as a result of 20 years (1988-2007) of genetic improvement (Jones et al. 2008).

\begin{tabular}{lcrcc}
\hline Livestock Industry & $\mathbf{C H}_{\mathbf{4}}$ & $\mathbf{N H}_{\mathbf{3}}$ & $\mathbf{N}_{\mathbf{2}} \mathbf{0}$ & $\mathbf{G W P}_{\mathbf{1 0 0}}$ \\
\hline Chickens - Layers & -30 & -36 & -29 & -25 \\
Chickens - Broilers & -20 & 10 & -23 & -23 \\
Pigs & -17 & -18 & -14 & -15 \\
Cattle - dairy & -25 & -17 & -30 & -16 \\
Cattle - beef & 0 & 0 & 0 & 0 \\
Sheep & -1 & 0 & 0 & -1 \\
\hline
\end{tabular}

Recent developments in animal breeding combine several biotechnologies together to impact multiple components of the breeder's equation (Figure 2). Advanced reproductive technologies that reduce the generation interval and increase the intensity of selection are being combined with genomic selection to increase the accuracy of selection in cell lines that are then cloned and transferred using embryo transfer to produce high genetic merit calves. This approach results in a substantial reduction in the generation interval by producing animals with the desired genetics in a one year timeframe.

A subset of biotechnologies are termed modern biotechnologies, and are defined in the Cartagena protocol as the application of a) in vitro nucleic acid techniques, including recombinant deoxyribonucleic acid (DNA) and direct injection of nucleic acid into cells or organelles, or b) fusion of cells beyond the taxonomic family, that overcome natural physiological reproductive or recombination barriers and that are not techniques used in traditional breeding and selection. This distinction between traditional and modern breeding methods is somewhat arbitrary as many of the techniques (Figure 2) involve the use of in vitro 
Van Eenennaam: The Current and Future Uses of Biotechnology in Animal Agriculture

techniques, and some of the recent breeding methods exactly mimic the natural processes of mutation and the end result is indistinguishable from naturallyoccurring variation.

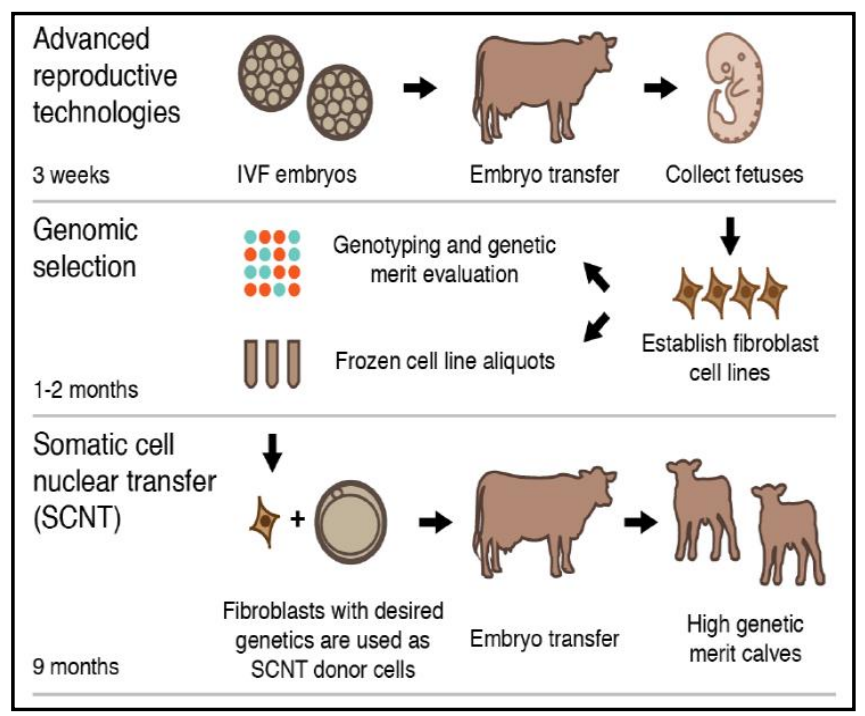

Figure 2. Production of high genetic merit calves using a range of biotechnologies. Image taken from Kasinathan et al. (2015).

Some have argued that if genetic modification has "for at least part of the procedure, been handled outside the organism by people" then the resulting organism is a genetically modified organism or GMO (Cotter et al. 2015). Using this definition, many animal breeding techniques that are currently a routine part of genetic improvement programs shown in Figure 2 (embryo transfer, ovum pick up, embryo transfer, artificial insemination, in vitro fertilization, somatic cell nuclear transfer cloning) would result in a GMO.

\section{Genetic Engineering}

Genetic engineering (GE) is a process in which scientists use recombinant DNA (rDNA) technology to introduce desirable traits into an organism. Because the genetic code for all organisms is made up of the same four nucleotide building blocks, this means that a gene encodes the same protein whether it is made in an animal, a plant or a microbe. Recombinant DNA refers to DNA fragments from two or more different sources that have been joined together in a laboratory.
The resultant rDNA construct is usually designed to express a protein, or proteins, that are encoded by the gene(s) included in the construct. GE involves producing and introducing the rDNA construct into an organism so that new or changed traits can be given to that organism. A GE animal is an animal that carries a known sequence of rDNA in its cells, and passes that DNA on to its offspring. GE animals are sometimes referred to as living modified organisms, transgenic, GMOs or bioengineered animals. GE animals were first produced in the late 1970s. Forty years later, transgenic animals have been produced in many species, including those traditionally consumed as food, although most have not moved from the laboratory to commercialization (Table 3).

\section{Genetically Engineered Animals for Agriculture}

GE fits in as a component of the breeder's equation in that it introduces useful genetic variation into breeding programs. The real power of this technology is in bringing in genetic variation not available in the target species, especially for traits like disease resistance. DNA from viral and bacterial species pathogens can conceptually be used to permanently genetically-immunize species against microbial pathogens. A number of different GE animals have been produced by researchers globally, and those specifically targeting traits of agricultural importance (Table 3). To date, only one application has been approved for food purposes, the fast-growing AquAdvantage $^{\circledR}$ Atlantic salmon. This fish was approved in 2015 for commercialization under specific production conditions by the US Food and Drug Administration after a prolonged regulatory evaluation. As of March 2016, its future was still uncertain due to the introduction of a legislative bill to require a thirdparty review of the FDA's decision to pronounce AquAdvantage ${ }^{\circledR}$ salmon safe for human consumption.

Many of the goals listed in Table 3 are common traits included in the breeding objectives of livestock genetic improvement programs. Breeders could conceptually use GE alongside conventional breeding methods to facilitate genetic improvement. To date, the expense of the regulatory process has precluded the commercialization of GE animals for food purposes. There have been some GE animals approved for biomedical pharmaceutical production including goats, rabbits and chickens and also some trials using GE insects for pest control applications. 
Table 3. Examples of transgenic animals for agricultural applications. The only product to obtain regulatory approval is the AquAdvantage ${ }^{\circledR}$ fast-growing salmon (bold). Adapted from Lievens et al. 2015.

\begin{tabular}{|c|c|c|c|}
\hline Species & Transgene & Origin & Effect/Goal \\
\hline \multirow[t]{5}{*}{$\overline{\text { Cattle }}$} & Lysozyme & Human & Milk composition \\
\hline & $\operatorname{PrP}$ & Knockout & Animal health \\
\hline & $\alpha-, k-C a s e i n$ & Bovine & Milk composition \\
\hline & Omega-3 & Nematode & Milk composition \\
\hline & Lysostaphin & Bacterial & Mastitis resistance \\
\hline \multirow[t]{3}{*}{ Chicken } & alv6 envelope glycoprotein & Viral & Disease resistance \\
\hline & short hairpin RNA & Viral & Disease resistance \\
\hline & LacZ & Bacterial & Animal Health \\
\hline \multirow[t]{2}{*}{ Carp } & Growth Hormone & Piscine & Growth rate \\
\hline & Lactorferrin & Human & Disease resistance \\
\hline Catfish & Cercopin B & Insect & Disease resistance \\
\hline \multirow[t]{4}{*}{ Goat } & Lysozyme & Human-Bovine & Animal Health \\
\hline & Monosaturated fatty acid & Rat-Bovine & Mastitis resistance \\
\hline & Lactoferrin & Human & Prophylactic treatment \\
\hline & Human beta-defensin 3 & Human & Milk composition \\
\hline \multirow[t]{8}{*}{ Pig } & Phytase & E. coli-Mouse & Feed uptake \\
\hline & Growth hormone & Human-Porcine & Growth rate \\
\hline & cSKI & Chicken & Muscle development \\
\hline & Lysozyme & Human & Piglet survival \\
\hline & Unsat. fat. acid & Spinach & Meat composition \\
\hline & Omega-3 & Nematode & Meat composition \\
\hline & a-lactalbumin & Bovine & Piglet survival \\
\hline & $\mathrm{M} \times 1$ & Murine & influenza resistance \\
\hline \multirow[t]{3}{*}{ Salmon } & Growth hormone & Piscine & Growth rate \\
\hline & Lysozyme & Piscine & Animal health \\
\hline & wflAFP-6 & Piscine & Cold tolerance \\
\hline \multirow[t]{4}{*}{ Sheep } & IGF-1 & Ovine & Wool growth \\
\hline & CsK & Bacterial & Wool growth \\
\hline & Visna resistance & Viral & Disease resistance \\
\hline & $\operatorname{PrP}$ & Knockout & Animal health \\
\hline \multirow[t]{2}{*}{ Silkworm } & eGFP, DsRed, or mKO & Cnidarian & Silk color \\
\hline & A2S814 & Arachnid & Silk strength \\
\hline Trout & Follistatin & Piscine & Muscle development \\
\hline
\end{tabular}

\section{Gene Editing}

Gene editing is a technique that employs sitedirected nucleases (SDN) to precisely edit or change the genetic code. As the name gene editing suggests, these technologies enable researchers to add, delete, or replace letters in the genetic code. In the same way that spell check identifies and corrects single letter errors in a word or grammar errors in a sentence, gene editing can be used to identify and change the letters that make up the genetic code (i.e. DNA) within an individual.

Gene editing has many potential applications. For example, it can be used to correct diseases and 
Van Eenennaam: The Current and Future Uses of Biotechnology in Animal Agriculture

disorders that have a genetic basis. It could also be used to change a less desirable form of a gene (called an allele) to a more desirable allele without the need to introgress (repeatedly backcross) or bring in that allele through outcrossing with an animal that carries the desirable allele. Therefore, gene editing is really more like precision breeding where breeders can introduce the specific sequences that they would like to select for using gene editing technologies.

Gene editing is different from traditional genetic engineering. Continuing with the analogy of a word processor, genetic engineering enables a gene sequence of foreign DNA to be cut and pasted from one species to another; typically the location where the new DNA sequence inserts into the genome is random. Gene editing can add, delete, or replace a series of letters in the genetic code at a very precise location in the genome.

The basic idea behind gene editing is that molecular scissors called site-directed nucleases (SDN) are used to cut DNA at a specific location in the genome based on recognition of the specific, unique target DNA sequence. The cut site is then repaired using the DNA repair mechanisms of the cell. These repairs can be directed to introduce, delete, or replace a series of letters in the genetic code. This essentially enables the introduction of known, desired alleles based on what is understood about naturally-occurring genetic variation in the target species.

Without the addition of template DNA, the double stranded breaks created at a precise location in the genome by the nucleases are repaired by the cell's natural DNA repair mechanism (non-homologous end joining (NHEJ), and this typically results in single nucleotide changes, deletions or small (1-2 nucleotide) insertions at the DNA cut site, sometimes called SDN1. In this case, although the location of the cut site is very precise, the exact change that occurs when the DNA is repaired is random and so a number of different outcomes representing minor sequence changes are possible (Figure 3 ).

Supplied with a nucleic acid template, however, the double stranded breaks initiated by the nucleases are repaired via the cell's homologous recombination (HR) repair pathway whereby the template dictates the sequence resulting from the repair, allowing the introduction of the DNA sequence dictated by the template into the host genome. Such changes might range from nucleotide-specific changes, to large (whole gene) insertions or substitutions depending upon the template. The end result of this maybe a targeted SNP edit (e.g. the nucleotide $A$ at a given location in the genome is deliberately replaced by $\mathrm{T}$ ), the replacement of one naturally occurring allele with another naturally occurring allele at target genetic gene locus within a species, or the introduction of a novel DNA sequence as encoded by the template at the target location in the genome, sometimes called SDN3. There are many potential uses of this technology ranging from human medicine to plant and animal breeding.

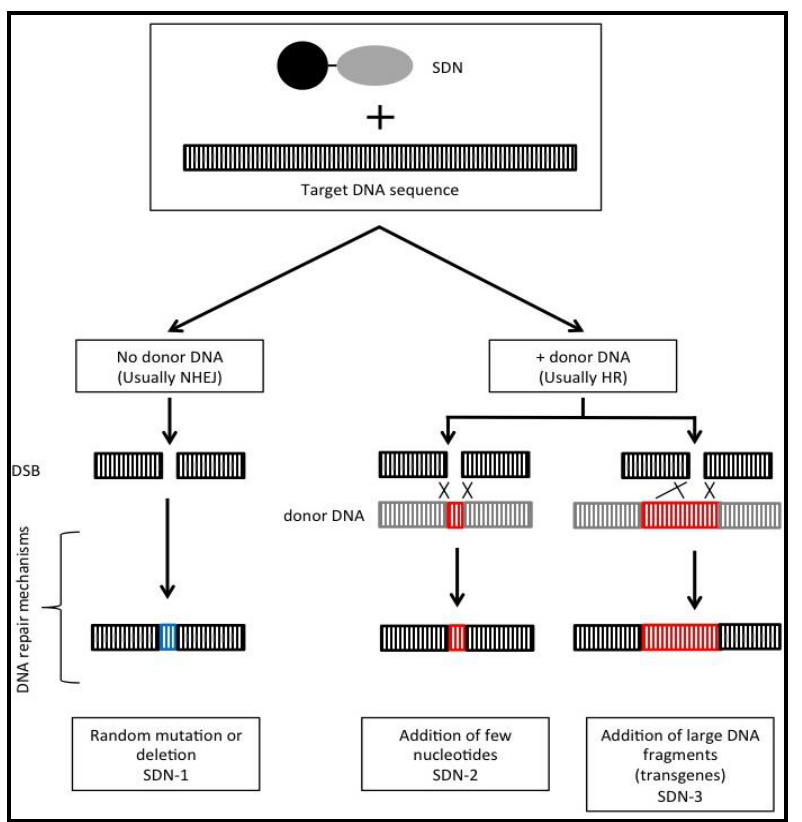

Figure 3. Schematic representation of intended modification by site-directed nuclease (SDN) types. Double-stranded break repair can occur via nonhomologous end-joining (NHEJ; SDN-1) or homologous recombination (HR) when a donor DNA is present (SDN-2; -3). Figure obtained from http://genok.no/wpcontent/uploads/2015/06/250615 Emerging technolog ies final.pdf.

\section{How Might Gene Editing be Used in Animal Breeding?}

In the last 5 years, genome editing technologies (zinc finger nucleases (ZFNs), transcription activatorlike effector nucleases (TALENs), and clustered regulatory interspersed short palindromic repeats 
(CRISPRs) associated system) have been used to mediate the generation of more than 300 edited pigs, cattle, sheep and goats (Tan et al. 2016). Table 4 lists some of those that were directly targeted to agricultural applications including product yield, animal health and welfare.

Gene editing has been used to produce genetically hornless Holstein dairy cattle by replacing the Holstein horned allele with the naturally-occurring Angus polled allele at the gene that is responsible for horn development (Tan et al. 2013), and to generate pigs with edits in the haplotype of a gene that may confer resilience to African Swine Fever Virus (Lillico et al. 2016). Another group of gene edited pigs are protected from porcine respiratory and reproductive syndrome (PRRS) virus, a particularly devastating disease of the global pork industry (Whitworth et al. 2016) Gene editing has also been used to introduce changes in the myostatin gene in sheep, cattle (Proudfoot et al. 2015), and goats (Ni et al. 2014). As the Latin origin of the word myostatin (muscle/stop) suggests, turning off this gene results in muscle growth. Naturally-occurring mutations in this gene have historically been selected by conventional animal breeders and are the genetic basis for the "double muscled" phenotype that is seen in cattle breeds like the Belgian Blue, and the bully phenotype in whippet dogs.

Gene editing effectively mimics the natural processes that form the basis of selective breeding programs, and for that matter, natural selection. Breeders work with the genetic variation that exists within a species, and that genetic variation ultimately arises from naturally-occurring mutations. Although the word "mutation" sounds negative, it simply refers to variations in DNA sequences. These variations, or mutations, are responsible for virtually all genetic differences that exist between individuals, such as having blue eyes instead of brown.

Although different mammals have many of the same genes, some people do not appreciate that the genetic code that makes up those genes differs among animals of different breeds, and even among animals within the same breed. In fact, with the exception of identical twins, there are literally millions of DNA sequence variations between two individuals of any species. For example, an enormous number of genetic variants have accumulated within cattle since the advent of domestication and selective breeding due to the naturally-occurring processes that lead to a small number of mutations each generation. In one recent analysis of whole-genome sequence data from 234 taurine cattle representing three breeds, more than 28 million variants were observed, including insertions, deletions and single nucleotide variants (Boussaha et al. 2015). A small fraction of these mutations are those that have been selected by breeders; most of them are silent and have no impact on traits of importance to breeding programs. Occasionally, such mutations result in a genetic condition such as red or black coat color or an undesirable disease condition such as dwarfism.

Table 4. Examples of successful gene edited agricultural applications in food animal species.

\begin{tabular}{|c|c|c|c|}
\hline Species & Target & Publication & Effect/Goal \\
\hline \multirow[t]{2}{*}{$\overline{\text { Cattle }}$} & Polled & Tan et al. 2013 & No horns \\
\hline & Myostatin & Proudfoot et al. 2015 & Increased muscle growth \\
\hline Chicken & Ovalbumin & Park et al. 2014 & Elimination of ovalbumin in egg \\
\hline Goat & $\begin{array}{l}\text { Myostatin } \\
\text { Prion protein } \\
\text { Beta-lactoglobulin }\end{array}$ & Ni et al. 2014 & $\begin{array}{l}\text { Increased muscle growth } \\
\text { Elimination of prion protein } \\
\text { Elimination of milk allergen }\end{array}$ \\
\hline \multirow[t]{2}{*}{ Pig } & CD163 & Whitworth et al. 2015 & PRRSV Resistance \\
\hline & RELA & Lillico et al. 2016 & African Swine Fever Resistance \\
\hline Sheep & Myostatin & Proudfoot et al. 2015 & Increased muscle growth \\
\hline
\end{tabular}


Van Eenennaam: The Current and Future Uses of Biotechnology in Animal Agriculture

\section{How Might Gene Editing Intersect with Conventional Breeding?}

Data coming out of some of the large-scale genomic and sequencing projects are revealing situations in which the sequence of one naturallyoccurring allele results in superior performance than observed when animals inherit an alternative allele of that gene. It is envisioned that it might be possible to edit an animal's genome to the superior allele, and to do that at several genomic locations, or for several different genes. The advantage of gene editing over conventional selection to move these naturallyoccurring alleles from one animal to another is that favorable alleles rarely all occur in one single individual and editing offers the opportunity to increase the frequency of desirable alleles in an individual or a breed more rapidly than could occur through conventional breeding.

One could potentially envision editing several alleles for different traits - such as disease resistance, polled and to correct a known genetic defect - all while using conventional selection methods to keep making genetic progress towards a selection objective. One study found that combining gene editing with genomic selection could improve the response to selection four fold after 20 generations (Jenko et al. 2015).

It should be remembered that complex traits are typically impacted by many different genes. It is not likely that all of the genes impacting such traits are known, nor is it typically evident which might be the desirable molecular edits for these genes (i.e. what is the sequence of the desirable allele). It is likely that editing will be focused on large effect loci and known targets to correct genetic defects or decrease disease susceptibility, and conventional selection will continue to make progress in selecting for all of the many small effect loci that impact the complex traits that contribute to the breeding objective.

Gene editing offers an approach to translate the thousands of SNP markers discovered through livestock sequencing projects, the information obtained from numerous genome wide association studies, and the discovery of causative SNPs (Quantitative Trait Nucleotides; QTNs) into useful genetic variation for use in animal breeding programs (Hickey 2013).

\section{Will Gene Editing be Regulated?}

At the current time, it is unclear whether gene editing will be formally regulated as is the case with animals that have been produced using genetic engineering. Animal breeding per se is not regulated by the federal government, although it is illegal to sell an unsafe food product regardless of the breeding method that was used to produce it. Gene editing does not necessarily introduce any foreign genetic DNA or transgenic sequences into the genome, and many of the changes produced would not be distinguishable from naturally-occurring alleles and variation. As such, many applications will not fit the classical definition of genetic engineering. For example, many edits are likely to edit alleles of a given gene using a template nucleic acid dictated by the sequence of a naturally-occurring allele from the same species (e.g. the hornless Holstein example described earlier used template sequence based on the polled allele from Angus). As such, there will be no novel DNA sequence present in the genome of the edited animal, and likewise no novel phenotype associated with that sequence. It is not evident what unique risks might be associated with an animal that is carrying such an allele given the exact same sequence and resulting phenotype that would be observed in the breed from which the allele sequence was derived.

It is possible that nucleases might introduce double stranded breaks at locations other than the target locus, and thereby introduce alterations elsewhere in the genome. Such off-target events are analogous to spontaneous mutations and can be minimized by careful design of the gene editing reagents.

Governments and regulators globally are currently deliberating about how or if gene-edited animals should be regulated. It is likely that gene editing will be considered on a case-by-case basis depending upon the novelty of the edited DNA sequence and the resulting attributes or phenotype displayed by the animal. Although gene editing is a very versatile tool, many applications will likely result in animals carrying desirable alleles with sequences that originated in other breeds or individuals from within that species. As such, this process is directly analogous with conventional breeding. There is a need to ensure that the extent of regulatory oversight is proportional to the 
unique risks, if any, associated with the novel phenotypes. This question is of course important from the point of view of technology development, innovation and international trade.

\section{Conclusion}

Biotechnology is a broad term that encompasses many technologies that are used in animal agriculture. Emerging biotechnologies offer great potential, especially in the area of animal breeding. While regulation to ensure the safety of new technologies is necessary, in a world facing burgeoning demands on animal agriculture from population and economic growth, unaccountable delay of safe, effective technologies is a luxury that food security can ill afford.

Acknowledgements. The author acknowledges research support from the USDA for grants (2015$67015-23316$; 2015-33522-24106) that involve genome editing in livestock.

\section{References Cited}

Boussaha, M., D. Esquerré, J. Barbieri, A. Djari, A. Pinton, R. Letaief, G. Salin, F. Escudié, A. Roulet, S. Fritz, F. Samson, C. Grohs, M. Bernard, C. Klopp, D. Boichard, and D. Rocha. 2015. Genome-wide study of structural variants in bovine Holstein, Montbéliarde and Normande dairy breeds. PLoS ONE 10: e0135931.

Capper, J.L., R.A. Cady, and D.E. Bauman. 2009. The environmental impact of dairy production: 1944 compared with 2007. Journal of Animal Science 87: 2160-2167.

Cotter, J., D. Zimmermann, and H. van Bekkem. 2015. Application of the EU and Cartagena definitions of a GMO to the classification of plants developed by cisgenesis and gene-editing techniques. Greenpeace Research Laboratories Technical Report (Review) 072015. 18 p. http://www.greenpeace.to/greenpeace/wpcontent/uploads/2015/11/Application-of-GMOdefinitions-to-plants-developed-by-cisgenesis-andgene-editing-techniques.pdf

Food and Agriculture Organization (FAO). 2010. Current status and options for livestock biotechnologies in developing countries. FAO International Technical Conference, Agricultural biotechnologies in developing countries: Options and opportunities in crops, forestry, livestock, fisheries and agro-industry to face the challenges of food insecurity and climate change. Guadalajara, Mexico, March 1-4 2010. Report ABDC$10 / 5$. 57

p. http://www.fao.org/fileadmin/user upload/abdc/docume nts/livestock.pdf.
Foote, R.H. 1999. Development of reproductive biotechnologies in domestic animals from artificial insemination to cloning: a perspective. Cloning 1: 133142.

Foote, R.H. 2002. The history of artificial insemination: Selected notes and notables. Journal of Animal Science 80: 1-10.

Hickey, J.M. 2013. Sequencing millions of animals for genomic selection 2.0. Journal of Animal Breeding and Genetics. 130: 331-2.

Hill, W.G., and M. Kirkpatrick. 2010. What animal breeding has taught us about evolution. Annual Review of Ecology, Evolution, and Systematics 41: 1-19.

Jenko, J., G. Gorjanc, M.A. Cleveland, R.K. Varshney, C.B.A. Whitelaw, J.A. Woolliams, and J.M. Hickey. 2015. Potential of promotion of alleles by genome editing to improve quantitative traits in livestock breeding programs. Genetics Selection Evolution 47:114.

Jones, H.E., C.C. Warkup, A. Williams, and E. Audsley. 2008. The effect of genetic improvement on emissions from livestock systems. Page 6 in Proc. 59th European Federation of Animal Science (EAAP).

Kasinathan, P.M., B.M. Swallow, G.J. Rowlands, R.L Kruska, and P.N. de Leeuw. 2015. Acceleration of genetic gain in cattle by reduction of generation interval. Scientific Reports 5: 8674.

Lievens, A., M. Petrillo, M. Querci, and A. Patak. 2015. Genetically modified animals: Options and issues for traceability and enforcement. Trends in Food Science \& Technology 44: 159-176.

Lillico, S.G., C. Proudfoot, D.F. Carlson, D. Stverakova, C. Neil, and C. Blain. 2016. Mammalian interspecies substitution of immune modulatory alleles by genome editing. Scientific Reports 6: 21645.

Ni, W., J. Qiao, S. Hu, X. Zhao, M. Regouski, M. Yang, I.A. Polejaeva, and C. Chen. 2014. Efficient Ggene knockout in goats using CRISPR/Cas9 system. PLoS ONE 9: e106718.

Olesen, I., A.F. Groen, and B. Gjerde. 2000. Definition of animal breeding goals for sustainable production systems. Journal of Animal Science 78: 570-582.

Park, T.S., H.J. Lee, K.H. Kim, J.S. Kim, and J.Y. Han. 2014. Targeted gene knockout in chickens mediated by TALENs. Proceedings of the National Academy of Sciences of the United States of America 111: 1271612721.

Proudfoot, C., D.F. Carlson, R. Huddart, C.R. Long, J.H. Pryor, and T.J. King. 2015. Genome edited sheep and cattle. Transgenic Research 24: 147-153.

Tan, W., D.F. Carlson, C.A. Lancto, J.R. Garbe, D.A. Webster, P.B. Hackett, and S.C. Fahrenkrug. 2013. Efficient nonmeiotic allele introgression in livestock using custom endonucleases. Proceedings of the National Academy of Sciences of the United States of America 110: 16526-16531. 
Tan, W., C. Proudfoot, S.G. Lillico, and C.B. Whitelaw. 2016. Gene targeting, genome editing: from Dolly to editors. Transgenic Research 25:273-287.

VandeHaar, M.J., and N. St-Pierre. 2006. Major advances in nutrition: relevance to the sustainability of the dairy industry. Journal of Dairy Science 89: 1280-1291.

VanRaden, P.M. 2007. Improving animals each generation by selecting from the best gene sources. Duke Animal Law Conference. 4 p. https://aipl.arsusda.gov/publish/other/2007/Duke07 pvr. pdf
Whitworth, K. M., R. R.R. Rowland, C.L. Ewen, B.R. Trible, M.A. Kerrigan, A.G. Cino-Ozuna, M.S. Samuel, J.E. Lightner, D.G. McLaren, A.J. Mileham, K.D. Wells, and R.S. Prather. 2016. Gene-edited pigs are protected from porcine reproductive and respiratory syndrome virus. Nature Biotechnology 34:20-22.

Received for publication on March 1, 2016.

Accepted for publication on July 20, 2016. 